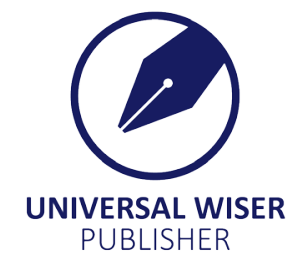

\title{
What are the Export Supply Constraints in the ECOWAS Zone?
}

\author{
Kwami Ossadzifo Wonyra ${ }^{1 *}$, Honoré Tenakoua ${ }^{2}$, Messan Kinvi ${ }^{1}$ \\ ${ }^{1}$ Université de Kara, Kara, Togo \\ ${ }^{2}$ Directorate General of Taxes, Burkina Faso \\ Email: wonyra.ossa@gmail.com
}

\begin{abstract}
This paper aims to analyze the constraints to the export supply in ECOWAS countries. The descriptive statistics as well as the gravity model techniques emphasize the weakness of the intra-regional trade in ECOWAS. Firstly, the countries of the zone with a relatively advanced economy, such as Nigeria, strongly participate in intra-regional exports while landlocked countries and small countries are major players in intra-regional imports. This is explained by the lack of diversification and non-complementarity of the product structure of the international trade. Secondly, we notice that the number of exchangeable products influence positively and significantly the participation in international trade as well as the GDP.
\end{abstract}

Keywords: exports supply constraints, intra-regional trade, gravity model

\section{Introduction}

The main pillar of the African Continental Free Trade Area (AfCFTA) is the regional economic communities. In order to achieve the objective assigned to the AfCFTA, that of promoting intra-African trade, a major constraint remains to be overcome. this is the problem of intra-regional and intra-African export supply.

According to the traditional theory of international trade, openness to international trade allows the partner countries to increase their respective levels of well-being ${ }^{[1]}$. Several arguments support this assertion. The first is that of investment. Openness to trade by increasing the size of markets, can spur investments that would not have been profitable in the domestic market alone. Commercial opening can also increase investment through imports, by giving to local investors' access to equipment that was not previously available, or that was available in the local market at higher cost. Moreover, if this openness increases the profitability of investments coming from abroad, it generates a rise in investments, which stimulates economic growth ${ }^{[2]}$. A second argument is the improvement of productivity. Openness to trade expose foreign investments, imports of goods and services to a stock of global technology that improves knowledge and therefore the efficiency of production processes. The opening will thus induce increased productivity. Besides, openness to trade favors competition. Local companies in countries engaged in world trade are forced to make investments and innovations in order to make their products more competitive (improve productivity, improve their products and lower production costs), leading to increased efficiency. Moreover, the specialization due to openness favors a more optimal use of the production factors $^{[2]}$

The 2014 World Trade Organization (WTO)' $\mathrm{s}^{[3]}$ report on world trade deals with the positive correlation between the volume of international trade and economic growth: "GDP is strongly influenced by international trade". The majority of countries that experienced the fastest economic growth in recent decades have been the most determined to implement an opening strategy. Chile, China, South Korea, Hong Kong, Indonesia, Malaysia, Mauritius, Singapore, Taiwan and Thailand are among the fastest-growing countries that have given the highest priority to stimulating export growth. China and India were among the most closed countries in the 1960s and 1970s. These two countries that initiated the opening in the 1980s, for the former, and in the 1990s for the latter, have seen their growth rates increase significantly ${ }^{[4]}$.

As for the African countries, which opened up to world trade while they were not ready for it (that is their productions were unable to compete with the goods produced in developed economies), they could not benefit from the profits highlighted by the theorists of international trade. In the wave of globalization that began in the 1990s, African countries and mainly the western part of the continent, exported commodities and imported finished products with high valueadded content ${ }^{[5]}$. This situation did not make it possible to boost economic activity nor guarantee job creation over a long

Copyright (C2020 Kwami Ossadzifo Wonyra, et al.

DOI: https://doi.org/10.37256/redr.122020558

This is an open-access article distributed under a CC BY license

(Creative Commons Attribution 4.0 International License)

https://creativecommons.org/licenses/by/4.0/ 
term. Even though most western-African economies have an average growth rate of $5 \%$, this rate does not accelerate development, leaving the majority of citizens in a precarious economic situation. In fact, the poverty rate in Africa is $40.7 \%$. The current global trade pattern is disadvantageous for West African countries. Nowadays, it is almost impossible for West African countries to create viable industries in the aforementioned sectors. The reason is that this requires a heavy investment that is difficult to sustain for the West African countries individually. In addition, foreign investors are not encouraged to invest in these sectors as marginal capital productivity is reduced by corruption, lack of infrastructure and lack of skills ${ }^{[6]}$. It is clear that it would be difficult for the West African countries to meet the challenge of integrating international trade individually. The most convincing alternative is that of regional economic integration ${ }^{[7]}$.

Regional integration can be seen as a necessary condition for economic and social development for African countries. This position is justified by several facts. First, most of these countries are too small to individually form viable economic spaces. On the one hand, they cannot set up production units large enough to enjoy economies of scale and operate at competitive costs. On the other hand, they have no bargaining power on the world economic scene and are marginalized in international negotiations. Africa accounts for only $2 \%$ and $3 \%$ respectively of world gross domestic product (GDP) and $\operatorname{trade}^{[3]}$. In addition, some countries in the continent face particular geographic or natural disadvantages (among which we have isolation and insularity). The signing of an economic integration agreement, such as the Economic Community of West African States (ECOWAS) framework, is a way among many, to handle the problem of the narrowness of the market. In an integration context, cooperation between States members plays an important role. The economic cooperation of the member States of a community is favorable to the exchanges, but within the countries of the ECOWAS, this cooperation is slow, with similar structure of exported products on the international trade level. Some economists explain that countries whose economic structure is similar, in the sense that they produce the same goods are not likely to exchange.

We draw our attention to the low level of ECOWAS intra-regional trade flows, which is partly attributable to the supply constraints undermining the productive sector ${ }^{[8-10]}$. Regional integration can generate trade creation ${ }^{[11]}$ if it takes place in a context where such constraints are effectively absorbed and where the supply of tradable goods has a reasonable level of elasticity. In fact, the export offer constitutes the fundamental element of participating in international trade. The other elements (customs duties, the exchange rate, transport costs...) that influence trade come into play only if there is a need to exchange goods and services. This is highlighted in the international trade literature. the Regional Economic Communities (RECs) in the Asian continent, in particular South Asia and Pacific Asia, have achieved export performance through the increasing access to the foreign market as well as the ability to export supply. Meanwhile, North America saw its trade decline, with a deterioration in supply capacity, despite having a very high level of access to the foreign market but [12]. One can wonder about the constraints to the export supply in the countries of the Economic Community of West African States.

There is a gap in the literature on the constraints to export supply in ECOWAS. Therefore, there is a need for investigating the challenge of integration of ECOWAS countries to international trade, and competitive product development. The objective of the present study is to help identify the elements that hinder exports between ECOWAS States. Specifically, we want to determine the supply capacity's effect on the intra-regional exports of ECOWAS, as well as the foreign market access effect on ECOWAS intra-regional exports. To achieve these objectives, we use gravity model estimated with the Pseudo-Poisson Maximum Likelihood (PPML) techniques. Our results reveal that countries with a relatively advanced economy, such as Nigeria, strongly participate in intra-regional exports while landlocked countries and small countries are major players in intra-regional imports. This is explained by the lack of diversification and noncomplementarity of the product structure of the international trade. In addition, we note that the number of exchangeable products influence positively and significantly the participation in international trade; as well as the GDP, which is an indicator of the level of development of a country.

The rest of the paper is as follow. The section 2 covers stylized facts. Literature review is presented in section 3 . Section 4 presents the methodology and data. Section 5 analyzes and discusses empirical results and Section 6 concludes.

\section{Stylized facts and emprirical review}

\subsection{Intra-regional trade performance}

Trade policy in the West Africa region is focused on strengthening trade between member states and the rest of the world. Yet, ECOWAS has been at a lower level of integration into international trade. This observation is noticed through the nature of its exchange with the rest of the world, ECOWAS trade is characterized by a relatively low level of its exports. One of the objectives of ECOWAS is to promote development through trade, with trade agreements with 
developed and emerging countries being established. However, for ECOWAS and for a number of African countries, the expansion of external sectors is latent (Figure 1).

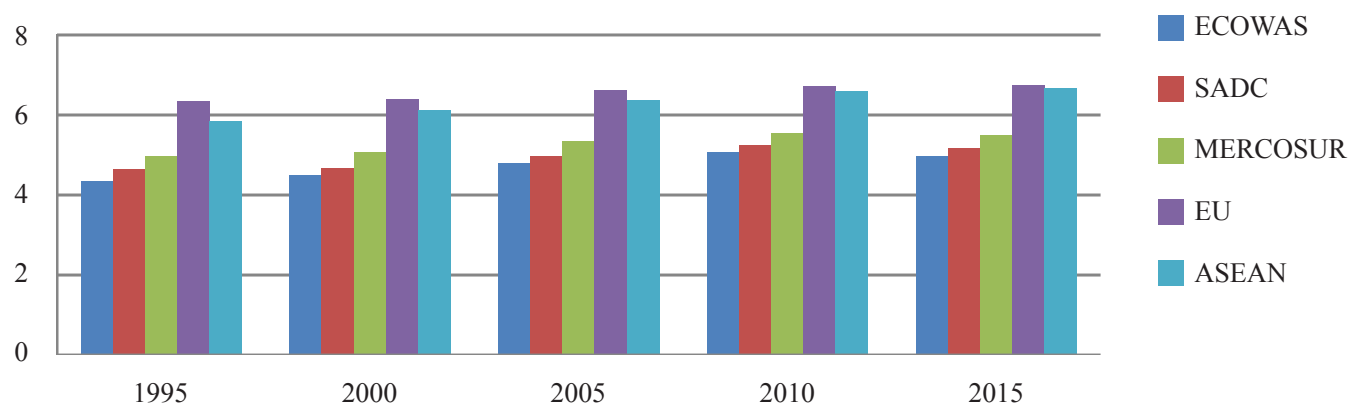

Figure 1. Logarithm of Exportation values by Regional Area between 1995 and 2015 Source: Author's calculation from UNCTADstat, 2017

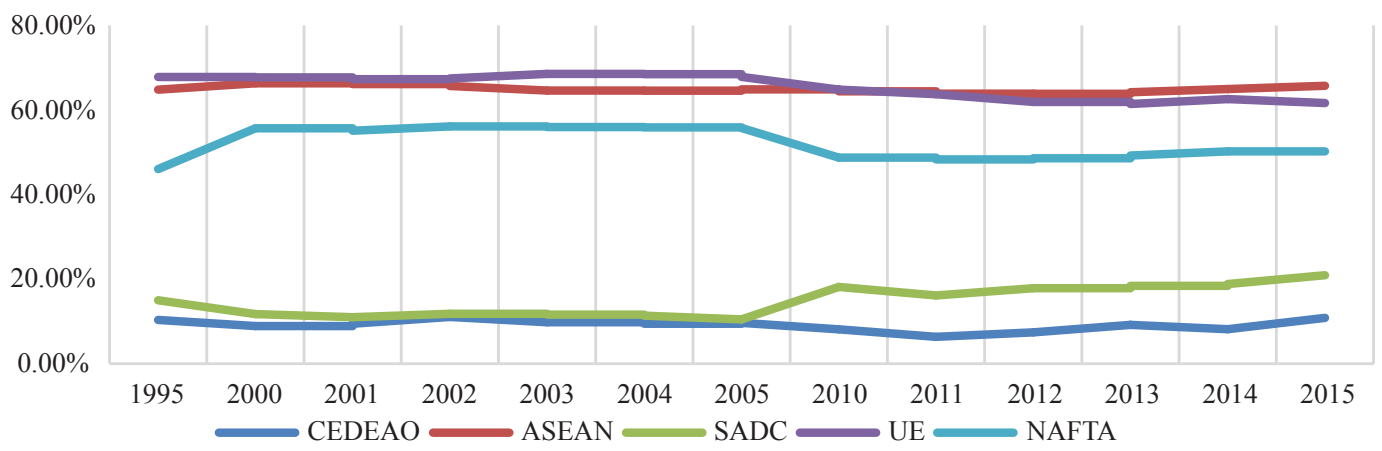

Figure 2. Intra regional trade in percentage of total exports

Source: Author's calculation from UNCTADstat, 2017)

Intra-ECOWAS trade represents only a very small percentage of the trade in the community (Figure 2). Intra-regional exports accounted for $10.84 \%$ of total exports in 2015 , compared to $11.06 \%$ in 2002 . The evolution of ECOWAS remains lower than in other regions of Africa, particularly in the countries of the South African Development Community (SADC), which experienced a nearly 50\% increase in the intra-African trade rate. In fact, they reached $20.92 \%$ in 2015 while in 2002 it was $11.81 \%$. Comparing to the percentage on other continents those of Africa remains very low. In particular, ASEAN, EU, NAFTA in 2015 were respectively $65.72 \%, 61.65 \%$ and $50.35 \%$.

The above graph show that the ECOWAS countries have very weak intra-Community trade. The explanation is twofold. The first is historical. Indeed, during the colonial period, the Africa continent was a source of raw material by colonizers. The commercial relationship with the settlers was to export raw materials to feed their industries. The new African states inherited this commercial relationship during the post-colonial period. This situation was fueled by the fact that Africa is a continent rich in natural resources. The second reason of the relates low level of intra-ECOWAS trade is related to the similarity of production structures in the countries and the low-income level.

In the ECOWAS zone, intra-community trade accounts for $10.9 \%$ of total trade. Nevertheless, when Nigeria is excluded, the ratio becomes $23.2 \%$ (27.1\% for exports, and $20.9 \%$ for imports). Like all RECs, the intensity of intracommunity trade is not the same for all member countries. In particular, the three landlocked countries of the region, Burkina Faso, Mali and Niger, are the main actors in intra-ECOWAS trade. Burkina has the highest ratio of intra-regional trade, $53 \%$, and Nigeria the lowest $4 \%$. Note that Nigeria capitalizes $76 \%$ and $46 \%$ of ECOWAS exports and imports ${ }^{[13]}$. However, its share in intra-regional trade is only $10 \%$ for imports and $35 \%$ for exports. An effort by Nigeria to increase intra-regional trade could significantly increase intra-Community trade (Figure 3).

The ECOWAS international trade statistics presented underline the low level of trade participation in the subregion, the limited set of these goods exported and concentrated on primary products, and the lack of diversification of these trading partners. These facts raise questions about the ability of ECOWAS to produce goods requested on the world market 
and its ability to conclude beneficial trade agreements.

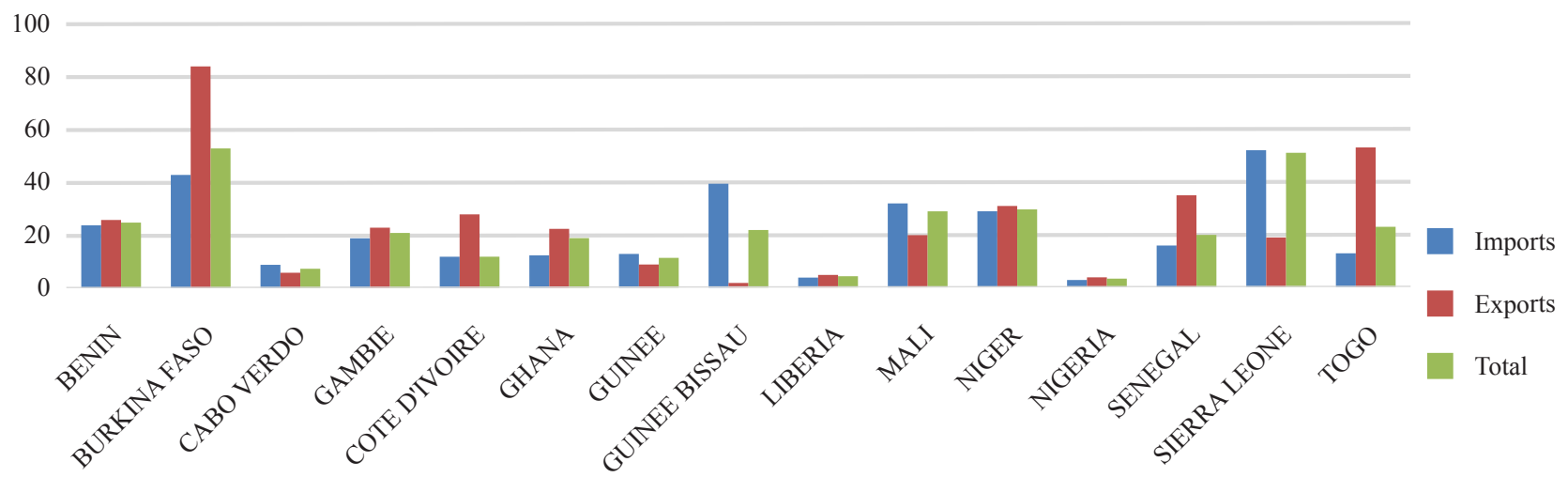

Figure 3. Share in intra-regional trade by countries of ECOWAS countries Source: Author's calculation from UNCTADstat, 2017

\subsection{Overview on empirical results}

In 1950, Viner highlighted the static effects of free trade on well-being. He opposes the creation of trade, which constitutes the gains in terms of the well-being of free trade, to the trade diversion, which materializes in losses of wellbeing. Viner's reflections are further enriched by the work of authors such as [14-19]. According to Viner's model, the static effects of integration result from a reallocation of economic production factors and natural resources leading to negative and positive effects on well-being. The model provides a tool to analyze the effects of FTAs on well-being by introducing the concepts of trade creation and trade diversion. The extent to which changes in well-being occur depends largely on the predominance of one or the other of these effects.

Afesorgbor and Bergeijk $\mathrm{k}^{[20]}$ conducted a comparative study of ECOWAS and SADC, using data from 35 countries for the years 1995-2006. They found that joining ECOWAS and SADC significantly increases the flow of bilateral trade. However, membership in SADC has a greater impact compared to ECOWAS. Their findings are supported by [21]. He pointed out that the creation of trade flows far outweighs the diversion of trade flows as far as the manufactured products of the European Economic Community (EEC) are concerned. According to him, the formation of the EEC has led to the creation of significant external trade flows ${ }^{[19]}$.

The dynamic effects of trade integration occur in the long term, because of the gains resulting from the FTA zones. These effects often result from economies of scale (due to a broader market); efficiency gains (due to the competitive environment and technology transfer); increased inflows of FDI, and elimination of contingent protection and tariff barriers. The largest economic gains can be derived from lower unit costs caused by economic cooperation and policy coordination $^{[22]}$, including those for regional transport and communications.

Fugazza $^{[12]}$ analyzed the determinants of export performance in the world's economic regions, as well as export supply constraints. The analysis revealed that, in general, the economic regions in the South and the Pacific Asia, Western and Eastern Europe, North America have good access to the foreign market, with good supply capacity and very good export performance. Conversely, RECs in Africa and Latin America have good access to the foreign market, but they fail to achieve export performance due to supply capacity constraints.

\section{Data and methodology}

\subsection{Variables and specification of the equation of the empirical model}

To highlight the constraints to export supply in ECOWAS countries, we develop the following econometric model based on the gravity model and the theoretical model of Fugazza ${ }^{[12]}$ and taken up by Wonyra ${ }^{[23]}$.

$$
\begin{aligned}
\ln X_{i j}= & \beta_{0}+\beta_{1} \ln G D P_{i}+\beta_{2} \ln \left(G D P_{j}\right)+\beta_{3} \ln \left(\text { Pop }_{i}\right)+\beta_{4} \ln \left(\text { Pop }_{j}\right)+\beta_{5} \ln \left(\text { Dist }_{i j}\right)+\beta_{6} \text { Col }_{i j}+\beta_{7} \text { Lang }_{i j}+\beta_{8} \text { Front }_{i j}+\beta_{9} \text { Enl }_{i} \\
& +\beta_{10} \text { Ecowas }_{i j}+\beta_{11} \ln F D I+\beta_{12} \operatorname{lnNtv}_{i}+\beta_{13} \text { Dda }_{i j}+\beta_{14} \text { Doc_Import }_{i}+\varepsilon_{i j}
\end{aligned}
$$


In this model, the dependent variable is the value of bilateral exports noted $X_{i j}$. i denotes the exporting country and $\mathrm{j}$ denotes the importing country. In the specification of our empirical model, the supply capacity is captured by the total number of varieties of tradable goods produced in the country i (Ntvi). As for access to the foreign market, we use the customs duty applied to exports of country i by the country of destination $\mathrm{j}$ (Ddaij).

The gravity model traditionally uses a set of explanatory variables in accordance with the theory presented above. We retain $P i b_{i}, P i b_{j}$ respectively the gross domestic product of the exporting country (i) and the importing country (j); $\operatorname{Pop}_{i}\left(\operatorname{Pop}_{j}\right)$ respectively the size of the population of country i (j); Dist ${ }_{i j}$ the distance between trading partners. These variables are often present in the previous studies of the gravity model. The measurement of distance is a controversial subject. In the empirical literature, three types of measurement are often mentioned. In the context of this work, we use the distance that connects the capital of country $i$ and to that of country $j$. The variable FDI measures the flows of foreign direct investments.

A set of dummy variables will also be utilized: Lang $_{i j}$ and Front ${ }_{i j}$ denote respectively common language and common border. They are equal to 1 , when the partners have the same official language and a common geographical boundary, respectively and 0 otherwise. takes the value 0 if country $\mathrm{i}$ is a coastal country and 1 otherwise. col $_{i j}$ the colonization variable, which takes the value 1 if the two countries in exchange have a historical relationship of colonization or if both countries have the same colonizer and 0 if neither of the two cases is verified. The dummy variable Ecowasij captures the membership to ECOWAS trade agreements or not. It takes values 1 if countries $i$ and $j$ are both members of ECOWAS and takes the value 0 if no. For this purpose, a set of partner countries in the ECOWAS member country is taken into account.

The variables of the model are classified into two categories. The first one is composed of continuous variables, expressed in logarithm; this is the case of GDP and distance. This form allows us to interpret the coefficient of these variables as elasticity. There are dummy variables (they take 0 or 1). These variables are called "multilateral resistance" or "multilateral resistance" is the case of language, isolation, a common past (colony, even colonizer). They are countryspecific and reflect individual characteristics or close links with partners that are likely to influence the volume of trade.

\subsection{Data and sources}

Our analysis consists of twenty-five countries, including the fifteen ECOWAS, and their main trading partners in Africa, Europe, Asia. The data cover 10 years from 2006 to 2015, which allows us to take into account recent realities. These are secondary data taken from different sources: export data were collected from the COMTRADE database; data on GDP, population, and foreign direct investment come from the World Bank's World Development Indicators (WDI) 2016 statistics. The multilateral resistance variables, namely: distance, isolation, colonization, and internal transport friction are obtained through the CEPII database.

\subsection{Estimation technique}

The present study uses the PPML method of [24]. The PPML method takes into account the strong presence of zero trade. The PPML is likely to take into consideration the problem of correlation between the error terms. Furthermore, the choice of the PPML method, is justified the non-stationarity of some variables as well as the recurring endogeneity issues of the gravity model.

\section{Results and discussions}

The results of the estimates above show that, in most cases, the signs of the variables of the gravity model are consistent with the expected sign. The coefficients of GDP and the population are positive, which means that bilateral trade between two countries is greater, when the size of the economies is large. Our estimation of the coefficient of the relationship between the GDP of the exporting nation and the bilateral exports indicates that a variation of $1 \%$ of the GDP induces a variation of $0.17 \%$ of the exports. A $1 \%$ change in partner country GDP results in a $0.06 \%$ change in bilateral exports. Bilateral exports vary by $0.04 \%$ and $0.02 \%$ respectively, when the population of the exporting country and that of the partner country each vary by $1 \%$.

The coefficient of the variable that captures the distance between trading partner countries shows that the distance has a significant and negative effect on trade, thus verifying the effect predicted by the theory, that the greater the distance between two countries, the more it is difficult to trade. The estimate of this coefficient indicates that bilateral exports fall by $0.10 \%$ when the distance between partners to trade increases by $1 \%$. Meanwhile, a border sharing between two countries is very beneficial for bilateral trade, according to our estimates. Indeed, the coefficient of the geographical proximity is positive indicating a positive effect on the bilateral trade. 
Table 1. Empirical analysis of supply constraints of ECOWAS countries

\begin{tabular}{|c|c|c|}
\hline Variables & ECOWAS and Rest of The World's trade & Intra-Regional trade \\
\hline LGDPi & $\begin{array}{c}0.172 * * * \\
(0.0279)\end{array}$ & $\begin{array}{c}0.1375 * * \\
(0.0732)\end{array}$ \\
\hline LGDPj & $\begin{array}{c}0.0637 * * * \\
(0.00457)\end{array}$ & $\begin{array}{c}0.0296 \\
(0.0113)\end{array}$ \\
\hline Lpopi & $\begin{array}{c}0.0456 * * * \\
(0.00978)\end{array}$ & $\begin{array}{c}-0.0106 \\
(0.0865)\end{array}$ \\
\hline Lpopj & $\begin{array}{c}0.0295 * * * \\
(0.00857)\end{array}$ & $\begin{array}{c}0.0959 * * * \\
(0.0193)\end{array}$ \\
\hline Ldist & $\begin{array}{c}-0.101 * * * \\
(0.0271)\end{array}$ & $\begin{array}{c}-0.2812 * * * \\
(0.0337)\end{array}$ \\
\hline Colij & $\begin{array}{l}0.108 * * \\
(0.0434)\end{array}$ & $\begin{array}{l}0.6493 \\
(0.736)\end{array}$ \\
\hline Langij & $\begin{array}{c}0.109 * * * \\
(0.0419)\end{array}$ & $\begin{array}{l}-0.3426 \\
(0.736)\end{array}$ \\
\hline Frontij & $\begin{array}{c}0.199 * * * \\
(0.0463)\end{array}$ & $\begin{array}{c}0.0821 \\
(0.0522)\end{array}$ \\
\hline Encli & $\begin{array}{c}-0.223 * * * \\
(0.0615)\end{array}$ & $\begin{array}{c}-0.1058 \\
(0.0842)\end{array}$ \\
\hline Ecowas & $\begin{array}{c}0.189 * * * \\
(0.0584)\end{array}$ & \\
\hline Lidei & $\begin{array}{c}-0.0511 * * * \\
(0.0132)\end{array}$ & $\begin{array}{c}-0.0607 * * \\
(0.0289)\end{array}$ \\
\hline Lntv & $\begin{array}{c}0.466^{* * * *} \\
(0.129)\end{array}$ & $\begin{array}{c}0.9219^{* * * *} \\
(0.0657)\end{array}$ \\
\hline Ddaij & $\begin{array}{c}0.00158 \\
(0.00265)\end{array}$ & $\begin{array}{c}-0.0002901 \\
(0.00377)\end{array}$ \\
\hline doc_import & $\begin{array}{c}0.00997 \\
(0.00705)\end{array}$ & $\begin{array}{c}0.0211 * * * \\
(0.0078)\end{array}$ \\
\hline Constant & $\begin{array}{c}-6.548 * * * \\
(0.449)\end{array}$ & $\begin{array}{c}-5.9731 * * * \\
(0.6692)\end{array}$ \\
\hline Observations & 1,550 & 929 \\
\hline R-squared & 0.599 & 0.505 \\
\hline
\end{tabular}

Note: $* * * \mathrm{p}<0.01, * * \mathrm{p}<0.05, * \mathrm{p}<0.1$

Source: author

The positive and significant sign of the language link (the fact that countries share the same official language or not) is an empirical proof that speaking the same language is a positive factor in bilateral exchanges. According to our work, when two countries speak the same language, they increase their trade by $0.10 \%$.

As the theory predicts, in our estimation, the relationship between remoteness and trade is materialized by a negative sign coefficient. The countries that are at the edge of the ocean benefit from this advantage while landlocked countries lose $0.22 \%$ in trade because of their landlocked. The variable that captures a country's membership in ECOWAS has a positive and significant sign, which means that ECOWAS is a community whose membership increases bilateral trade between member countries. In other words, the signing of the ECOWAS integration agreement creates trade.

In this paper, we have two sets of variables of interest. First, the domestic determinants of exports, captured by the GDP of the exporting country and the number of varieties of goods exported, reflect the exporting country's supply capacity. Second, the external determinants of export performance, which reflect access to the foreign market, are captured by the bilateral applied customs duties and the number of documents required importing into the partner country. Our results reveal that the coefficient of the variable that captures the number of varieties of goods exported has a positive and significant impact on the volume of bilateral exports. In fact, a variation of $1 \%$ in the number of varieties of goods exported leads to a variation of exports of $0.46 \%$. With regard to the coefficient of GDP analyzed above, this coefficient reflects a country's ability to supply the foreign market when its domestic production is large.

The coefficient of the tariff barriers' variable is not significant. This shows that tariff barriers are not a major obstacle to the trade of ECOWAS countries with their trading partners. As for the number of documents needed to import into the partner country (to a certain extent of administrative obstacles), the coefficient is not significant. This would mean that countries do not face administrative barriers when exporting to developed countries.

In summary, the ECOWAS countries are not limited in their exchanges by external constraints but rather by internal constraints (in other words by their supply capacities). These results are consistent with that of Fugazza ${ }^{[12]}$. 
For intra-regional trade, estimates show that, within ECOWAS, GDP, whether of the partner country or the exporting country, positively and significantly affects bilateral trade. This fact is theoretically justified because countries export what they produce or import what their partners have produced. Indeed, the gross domestic product is used to satisfy domestic demand as well as external demand and when the gross domestic product increases, ceteris paribus, exports also augment. This positive relationship between bilateral exports and GDP is highlighted in other works, such as [25]. In another sense, this result informs that, in order, to increase intra-regional exchange the member countries must produce more. However, the evolution of GDP is relatively slow, which partly explains the weakness of intra-ECOWAS trade.

Most of the commodities traded by ECOWAS countries are agricultural goods. However, the evolution of the value added of these products is very low to significantly increase intra-regional trade in this sector. Moreover, these products are exchanged without transformations. Excluding Nigeria, whose added value per worker is the largest in ECOWAS (\$ 8578 in 2015), the other countries a have weak an added value. Production techniques in the agricultural sector have not really been improved over the years. Climatic hazards make it even more difficult to achieve good agricultural performance. Countries that manage to perform well in agricultural crops often lose a significant part of their agricultural production, due to the location of in rural areas and bad road infrastructures.

The number of varieties of exported goods is a variable that reflects the ability of the exporting country to produce goods that satisfy foreign demand. The coefficient of this variable is positive and significant. This suggests that the ECOWAS countries can significantly increase their exports by putting new products on the sub-regional market. It also signals the existence of a great potential for commercial exchange between ECOWAS member countries. This result is in line with the work of [26]. The ECOWAS sub-regional market is characterized by a basket of few produced goods, making the product range traded, very limited. Tariffs seem to have no effect on trade between the countries of the community. The coefficient of the bilateral tariff variable indicates that tariffs do not have a significant effect on trade between ECOWAS member states. Indeed, the ECOWAS countries are currently at the stage of the customs union of regional integration. This underlines that the community has already consolidate free trade and that the goods should move freely. This demonstrates the remarkable progress of the subregion in terms of free trade between member countries. This result is in line with the work of [27].

\section{Conclusion}

The analysis of the trade flows of the ECOWAS countries highlighted the relatively weak nature of its trade, both globally and in intra-Community trade. On the non-Community level, the ECOWAS countries are not competitive, pointing the hope for trade expansion towards intra-Community trade. This paper aimed at determining the constraints of the ECOWAS intra-community trade supply offer. We used the gravity model, over a period of ten years (2006-2015), for the 15 ECOWAS countries and their 10 main partners. We have identified the effects of internal and external determinants on exports. The internal determinants intervene in the supply capacity of the foreign market, whereas the external determinants take into account the access to the foreign market.

The analysis of the relationship between trade and its internal components has shown that, ECOWAS, in its exports, is constrained by a weak supply capacity. The GDP and the total number of varieties of goods exported by the ECOWAS countries affect this supply capacity. In order to boost their GDP, ECOWAS countries need to improve some factors such as the transport infrastructure, telecommunications, electrical energy, techniques in the agricultural sector, as well as the economic and political environments. As for the number of varieties of goods exported, the results show very little diversity. ECOWAS is in need of developing other sectors other than the agricultural one.

Our second objective is the analysis of the access to the foreign market with respect to exports. The analysis of the relationship between trade and its external uncovers that within ECOWAS, tariff barriers do not significantly influence bilateral trade.

\section{References}

[1] Benassy-Quere, A. Economie monétaire internationale, 2e éd. HAL: Université Paris1 Panthéon-Sorbonne; 2015. Available from: https://www.economica.fr/livre-economie-monetaire-internationale-2e-ed-benassy-quere-agnes,fr, 4,9782717868456.cfm.

[2] Van Beers, C. P., Linneman, H. Commodity composition of trade in manufacturing, and South-South trade potential. The Journal of Development Studies. 1991; 27(4): 102-122. Available from: https://doi.org/10.1080/ 00220389108422215 . 
[3] World Trade Organization. World Trade Report 2014-Trade and Development: Recent Trends and the Role of the WTO. Cambridge University Publishing; 2015. Available from: doi: https://doi.org/10.1017/S1474745615000269.

[4] Dwight, H., Perkins. Radelet, S., Lindauer, D. Economie du développement. Nouveaux horizons. 2008.

[5] Collier, P., Venables, A. J. Rethinking Trade Preferences: How Africa can Diversify its Exports. The World Economy. 2007; 30(8): 1326-1345.

[6] Osakwe, P. N. Transformative Regionalism, Trade and the Challenge of Poverty Reduction in Africa. Trade and Poverty Paper Series, No. 1. United Nations Conference on Trade and Development. 2015.

[7] Essien, A. E. Les 20 Ans de la Révision du Traité et les 40 Ans de la communauté Economique des Etats de l'Afrique de l'Ouest (CEDEAO)-Un rapport sur l'intégration en Afrique de l'Ouest. Comprendre l'intégration régionale en Afrique de l'Ouest-Une analyse multithématique et comparative, IAO-ZEI PAPIER. 2014. p.11-41.

[8] Bacchetta, M. Releasing Export Constraints: The Role of Governments. Paper presented at the AERC Collaborative Research Workshop on Export Supply Response Constraints in Africa, Dar es Salaam, Tanzania April. 2007.

[9] Oyejide. African Trade, Investment and Exchange Rate Regimes and Incentives for Exporting. Paper presented at the AERC Collaborative Research Workshop on Export Supply Response Constraints in Africa, Dar es Salaam, Tanzania April. 2007.

[10] Oyejide. Relaxing Export Supply Constraints and Promoting Export Expansion and Diversification in Africa: The Role of Special Export Development Strategies. African Development Review. 2007; 19(1): 96-122.

[11] Viner, J. The Customs Union Issue. New York: Carnegie Endowment for International Peace; 1950.

[12] Fugazza, M. Export Performance and its déterminants: Supply and demand constraints. UNCTD. Policy Issues in International Trade and Commodities Study Series No. 2. Geneva; 2004.

[13] ECA. African Union and African Development Bank Assessing Regional Integration in Africa (ARIA V): Towards an African Continental Free Trade Area. Addis Ababa; 2012.

[14] Corden W. M. Trade Policy and Economic Welfare. Oxford: Clarendon Publishing; 1974.

[15] Baldwin, R. E. The Political Economy of U. S. Import Policy. Cambridge, Mass.: MIT Publishing; 1985.

[16] Flam, H. Product Markets and 1992: Full Integration, Large Gains? Journal of Economic Perspectives. 1992; 6(4): 7-30. Available from: doi:10.1257/jep.6.4.7.

[17] Bhagwati J. Export-Promoting Trade Strategy: Issues and Evidence. The World Bank Research Observer. 1988; 3(1): 27-57.

[18] Bhagwati, J. Regionalism and Multilateralism: An Overview. In: Jaime de Melo, Arvind Panagariya. (eds.) New Dimensions in Regional Integration. Cambridge: Cambridge U Publishing; 1993. p.22-51.

[19] CEA, ECOWAS. La ECOWAS à 40 ans. Une évaluation des progrès vers l'intégration en Afrique de l'Ouest. 2015.

[20] Afesorgbor, S. K., Van Bergeijk, P. Multi-membership and the Effectiveness of Regional Trade Agreements in Western and Southern Africa: A comparative study of ECOWAS and SADC. SSRN Electronic Journal. 2011. Available from: doi:10.2139/ssrn.1766522.

[21] Robson, P. The economics of international integration, 2nd ed. London: George Allen \& Unwin; 1994.

[22] Panagariya. EU Preferential Trade Arrangements and Developing Countries. World Development. 2002; 25(10): 14151432.

[23] Wonyra, K. O. Regional Integration and Export Supply Constraints: Evidence from ECOWAS Zone. West African Journal of Monetary and Economic Integration. 2018; 18: 72-92.

[24] Tenreyro, S., Santos Silva, J. M. C. The Log of Gravity. Review of Economics and Statistics. 2006; 88(4): 641-658.

[25] Shuaibu, M. Does Trade Tariff Liberalisation Matter for Intra-ECOWAS Trade? International Journal of Business and Economic. 2015; 8(1): 83-112.

[26] Geda, A., Seid, E. H. The potential for internal trade and regional integration in Africa. Journal of African Trade. 2015; 2(1-2): 19-50.

[27] Ackah, Turkson, Opoku. Measuring Trade Costs in Economic Community of West African States (ECOWAS). Modern Economy Journal. 2013; 4: 56-65. Available from: http://dx.doi.org/10.4236/me.2013.41007. 